

WARSZAWA 1996 Vol. 7

Andrzej Lisowski

\title{
PERCEPTION OF NATURAL HAZARDS IN POLAND
}

In the middle of this century the institutions responsible for collective action against natural disasters took interest in the social perception of natural hazards. The studies were used as supplementary materials in implementing protection programmes against natural hazards. Those programmes overemphasized the importance of technical means of protection and assumed that human behaviour relating to natural hazards is stereotyped (prevention was supposed to be universally accepted and the people were supposed to react to the actual hazard with panic). Modern management concepts are critical of the excessive concentration of power in the hands of state authorities and advise that local communities should be more active in the area of protection. Narrowing of the state's role in that sphere makes it necessary to elaborate a new action strategy, a strategy which would take into account current social perception of natural hazards (Lisowski 1996).

In the present study perception is understood as the reflection of the information concerning a definite natural hazard by the human mind. It does not imply just passive registration of facts, but involves also an emotional reaction and valuation of the information which is ordered and assimilated.

Further the perception of natural hazards in Poland will be presented on the basis of the interviews taken in the years 1988-1989 from the people who, either directly or indirectly suffered from a flood or a severe - frosty and snowy - winter. The respondents (428) were the victims of floods in $1979,1982,1985$ and 1987 from the three parts of the country (the centraleast, the south-west and the south-east), and the inhabitants of towns in the Warsaw voivodships (230) and fruit-trees farmers from 33 voivodships of the country (146), affected by the latest severe winter of $1986 / 87$. Former flood victims were interviewed, whereas the questionnaires were distributed among the victims of winter hazards from towns of the Warsaw voivodship in the local schools and work places, and finally the fruit-tree farmers received them by post (Lisowski 1993a).

In Poland total losses by flood were estimated in $1960-1990$ at $0.3 \%$ of GNP (70\% of the loss fell on agriculture) and the single cost item of maintaining road traffic in winter (1976-1990) was estimated at $0.2 \%$ of GNP. 
The greatest damage in terms of the area affected was caused by heavy rainfall and flood waters in 1980 (1.6\% GNP) and by the snowy winter 1978/79 (approx. 5\% GNP). The loss by flood tended to decrease and between 1980-1990 amounted to 0.1\% of GNP. On the other hand, the flood damage to rural and urban settlements proved to be greater. The sixties were a decade with the most frosty and snowy average winter season (particularly 1962/63, 1963/64, 1968/69, 1969/70). Winters in the eighties were milder, but there was a large number of serious breakdowns of vehicles and urban technical infrastructure $(1984 / 85,1986 / 87)$ even with the improved traffic conditions on roads and railways (Lisowski 1992). Early in $198732 \%$ of fruit-trees were frost bitten and perished.

The estimates of the losses reported by the victims were generally consistent with the records of the institutions for protection against natural hazards, as well as the press reports (Lisowski 1993b). The loss in human life and health by these causes was not significant (only 21 fatal cases of flood 1960-1990). Some casualties in the neighbourhood were reported by four respondents only as probable indirect consequences of the flood. Temporary or permanent physical health damage due to floods was declared by $27 \%$ respondents. The main problem for the victims was material loss, particularly when it affected their own households. Total or substantial damage of the house by flood was reported by about $40 \%$ of the former flood victims (54\% of respondents were temporarily evacuated for a period ranging from a few days to a few months), and in January $198758 \%$ of urban population were affected by the breakdowns of water and energy supply systems in their homes. The losses outside the homes were not given as much attention, especially if the functioning of households was not seriously affected. Urban dwellers and elderly people assessed their losses as considerable more frequently than other categories of respondents.

An important role in the perception of losses was played by the time gone since the loss had occurred. The people who admitted that the natural hazard had made an impact upon their living conditions (about $70 \%$ of the victims of floods and fruit-tree farmers) were mainly those who had incurred losses not longer than three years before the survey was carried out. It is worth noting that the victims of floods which had occurred 7 to 10 years before the survey declared that they still felt the impact of the flood on their mental condition in particular (70\%). This shows that just after the disaster people suffer most from the deterioration of living conditions, but as time passes and material losses are liquidated, they keep bad memories of the hard experience and problems. That was reflected by a comment given by a victim of the flood in the region of Mazovia: People still have been suffering from moral consequences of the flood, rather than from the material ones.

Emergency relieve was selective and reached the people who needed it. Local authorities were criticized for the failure to give warning about the 
imminent sudden flood early enough to let the people protect their wealth (ice-jam flood of 1982, flash flood of 1987). Most victims of the flood who had been evacuated regarded that as a necessary measure and would agree to be evacuated in another case of emergency, except some people from Plock area, who complained about larcenies during their absence (1982). People were more critical about loss compensation schemes than about emergency relieve (in the case of flood $38 \%$ and $19 \%$ respectively). Negative opinions about both emergency action and compensation schemes were expressed mainly by the inhabitants of towns and elderly people, but no correlation was found between those negative opinions and the size of material loss. Farmers felt satisfied with the indemnities paid for the loss in crops by flood, but the indemnities paid for damage to structures and movables they considered to be insufficient .

Flood damage, according to the respondents, has an exceptionally longlasting effect. In the Mazovia region 32\% of the former victims of floods complained about the loss they had incurred as long as 7-10 years before (damp in the house, falling off plaster, cracking walls), whereas in the south of Poland $50 \%$ of respondents complained about similar problems 1-3 years after the flood. No correlation was found between such statements and the negative opinion about loss compensation. The people who complained most about their loss were the ones whose loss was considerable. Also fruit-tree farmers complained about the great loss they had incurred, and only $45 \%$ considered that in five year's time their output would be as high as in 1986 . Even those forecasts, however, proved to be too optimistic, as the yields of 1990 were equal to just $25 \%$ of the 1986 yields which were exceptionally good in the history of fruit-growing in Poland.

Country people, as compared to the urban dwellers, took less critical attitude to loss compensation, were more prepared to help each other when a flood occurred, judging from their past experience they tended to think they would manage, thanks to their personal enterprise, to cope with the loss by flood (79\% in the country and $60 \%$ in towns). In Pultusk, one of the towns of the Mazovia region, only $26 \%$ of the respondents answered they still suffered from the loss, but over $50 \%$ admitted they knew the people who did not obtain sufficient compensation of the loss by flood. In Mazovia, over $60 \%$ respondents considered that the losses were due to neglect (maintainance of anti-flood structures). In fact respondents had excessively trust the resistance of the earth embankments protecting the areas down the Vistula and Narew rivers.

In the research on the perception of natural hazards by potential victims and decision-takers it is assumed that the capital of knowledge and experience accumulated in that field is an important factor influencing attitudes towards protective measures. Among the former flood victims $47 \%$ thought that a flood would occur again, and $49 \%$ of fruit-tree farmers and $34 \%$ of the town dwellers tried to predict the date. Those forecasts proved to 
be rather accurate. Between 1960-1990 severe winters in Poland occurred every four years on the average, whereas frost caused bad losses in orchards every 15 years $(1962 / 63,1986 / 87)$. Among the interviewed inhabitants of Warsaw $44 \%$ expected that severe winter would occur within the following 5 year's period (further $32 \%$ of the urban dwellers within 5-10 years), and $62 \%$ of fruit-tree farmers expected severe damage by frost to occur again within the period of the following 10-20 years.

Floods were perceived as the most significant past events. Out of all the dates of floods recorded over $80 \%$ fell in the 30 years preceding the survey, whereas $70 \%$ of the dates of severe winters were recorded in the period of only 11 years. From $11 \%$ to $24 \%$ of respondents in Silesia region were able to correctly list the dates of the worst floods, which had occurred between 1939-1977. The dates of severe winters in the past were not listed as correctly due to a specific nature of winter hazards. Only $23 \%$ of respondents listed the harshest winter of $1978 / 79$, and the mention of severe winters in the 1960 s was made only occasionally. The importance of natural hazards in social consciousness is testified to by the attitude of respondents towards the survey. The flood victims occasionally refused to talk to interviewers or were unwilling to do so, but only $47 \%$ of fruit-tree farmers sent back the filled in questionnaires by post and only $58 \%$ of the questionnaires from work places and schools in Warsaw were returned. In sum, natural hazards are not perceived as very significant problems. $27 \%$ of respondents regarded floods to be local issues, mainly in the southern part of the country, and among the possible features of faulty location of an orchard $25 \%$ of fruittree farmers listed such a location which is conducive to damage by frost.

In southern Poland where floods occur frequently $(72 \%$ of total country losses between $1960-1972$ and $48 \%$ between 1975-1987) and where they had not occurred longer than 1-3 years before the survey local inhabitants expected another flood and regarded floods as a permanent hazard to their places. Those people had had the experience of flood at least twice before and recently they frequently incurred considerable losses. These findings largely confirm the research results obtained by G. F. White and his collaborators (Burton et al. 1978). The perception of severe winters by the respondents depended mainly on their educational status. Winter hazards, due to their pervasive nature, tend to have rather indirect consequences and their perception can be accounted for mainly by general knowledge of respondents rather than by their personal experience. Nearly twice as many respondents with higher and secondary education than with elementary and vocational education tried to predict the date of another severe winter or tell which of the past years winter season was harsh. The answers given by fruit-tree farmers to the question on the incidence of damage by frost were relatively accurate and this can be attributed to their education and professional training (more than $80 \%$ had secondary or higher education). 
The knowledge of natural hazards and the relevant experience that a man might have gained do not suffice to make predictions concerning his future behaviour in another instance of natural hazard. One must be persuaded about the existence of a direct link between the occurrence of hazard and the probability of own losses. People should realize that one can control different phenomena in one's own environment and take protective measures against them. In fact $76 \%$ of respondents believed that the losses could be prevented by collective actions, but only general or even stereotyped measures were suggested. Former flood victims mentioned first of all the means provided by hydraulic engineering (75\%): embankments and channel enlargements; urban dwellers, on the other hand, mentioned appropriate preparation to winter season by the sectors of heat engineering, public transport and by snow clearing and road traffic maintenance services.

The respondents thought that people tend to be well prepared to moderately intensive natural hazards and that the consequences of winter hazards can be best prevented individually (45\%). The proposed means, however, were stereotyped (mainly appropriate heating, clothing and storing of food products). Only rarely did the respondents emphasize the necessity of adjusting schedules of daily activities and limiting travels round the town. It was also rare that they declared readiness to help with snow clearing in the neighbourhood (7\%). Fruit-tree farmers, familiar with winter hazards, could - except for two - enumerate at least three means of preventing damage by frost (mainly frost-resistant varieties of fruit-trees, appropriate location of an orchard and cional rootstocks). Only $25 \%$ of the former flood victims, on the other hand, considered that they could take protective actions against flood losses by themselves. This implies that what they had in mind were emergency relieve actions (evacuations, protection of personal belongings) rather than preventive activities. Among the former victims of natural hazards, the people with higher and secondary education or the ones having greater awareness of those hazards listed both collective and individual means of protection more frequently than other categories of respondents.

Even the people who had incurred losses not so long before the survey were little aware of the natural hazards due to low incidence of such events, occasional casualties, and general familiarity of the people with causes and effects of those hazards. On the other hand, by contrast to pervasive hazards, intensive hazards appear suddenly, affect a limited area but cause greater losses per person, affect households directly and result in the loss which are much more difficult to make for. Pervasive hazards with much more widespread consequences may, on the other hand, be worse for the country as a whole, just as the case of 1978/79 winter showed. Rural areas are more exposed to natural hazards but local people prove to be better adapted to them and less helpless when faced with the disaster and more 
inclined to help each other, they are less critical about emergency relieve and loss compensation schemes. In the Opole voivodship (Silesia region), where flood losses over the period of $1975-1990$ proved to be greatest (8\% of total country losses) can even identify a sort of disaster culture as the inhabitants regard floods as temporary hardships rather than as natural disasters, although they are fully aware of their consequences. The inhabitants of towns and aged people tend to perceive the consequences of natural hazards as severe, independently of the size of the loss incurred.

This kind of perception of natural hazards in Poland may not be conducive to greater efficiency of preventive regulatory policies. A broad awareness campaign, if launched in the period of socio-economic transition of the country may not meet with sufficient local response as the people may be too busy with resolving of their current, urgent problems associated with an adjustment to market economy. In the initial years of economic transition a tendency was recorded towards narrowing of the state's role of the security guarantor with respect to particular consequences of natural disasters (the mandatory insurance of the crops and moveable property in the rural areas was abolished in 1990, spending on flood protection and road maintenance was cut down), but with regard to graver consequences of major natural hazards in fact the state is forced to loss compensation. The payments to farmers after the droughts (1992 and 1994) and to the victims of last flash flood in 1995 confirmed that the people as well as the local governments expected to get financial compensation from the state. Setting up of the National Rescue and Fire Fighting System (1995) which is meant, among other things, to provide emergency relieve to the victims of natural disasters, is the evidence that the state would confine its role in prevention to emergency relieve and loss compensation.

\section{REFERENCES}

Burton I., Kates R.W., White G.F., 1978, The environment as hazard, Oxford University Press, New York.

Lis ow s ki A., 1992, The effects of winter hazards on road transportation in Poland, Miscellanea Geographica, vol. 5, Faculty of Geography and Regional Studies Warsaw University, p. 147-152.

Li so w s k i A., 1993a, Skutki występowania wybranych zagrozen naturalnych $w$ Polsce (The effects of selected natural hazards and their perception in Poland), Faculty of Geography and Regional Studies, Warsaw University.

Li sow ski A., 1993b, Percepcja klęsk żywiołowych w Polsce (Perception of natural disasters in Poland), in: Risques naturels: prevision, prevention, Seminaire franco-polonais, Warszawa 18-19 listopada 1993, Instytut Meteorologii i Gospodarki Wodnej, Warszawa, p. 129-135.

Li sow ski A., 1996, Antropogeniczne uwarunkowania klęsk żywiołowych (Human preconditions of natural disasters), Przeglqd Geograficzny, vol. 68, z. 1-2 (p. 67-78). 